\title{
Geotechnical Characterization of some Clayey Soils for Use as Landfill Liner
}

\author{
*11OLUWAPELUMI, O. OJURI \\ Department of Civil and Environmental Engineering, Federal University of Technology, \\ Akure, Ondo State, Nigeria, E-mail: ojurip@yahoo.com
}

\begin{abstract}
Waste management is one of the major challenges faced by municipality officials, public health engineers and environmentalists in their quest to protect and preserve our environment. Construction and operation of an engineered sanitary landfill ensures proper waste management with the protection of human and ecosystem health. This paper presents the results of geotechnical investigation carried out on clayey soils from three selected pottery areas in Oke Ogun, Oyo State; to assess their suitability for use as landfill liner. Samples were collected at three locations namely: Ajetunmobi village, sample A; Adegbite area, sample B; and Arigangan area, sample $\mathrm{C}$. Basic index characterization tests conducted on the samples revealed percentage fines for samples A,B and $\mathrm{C}$ were $32.7 \%, 28.3 \%$ and $37.0 \%$ respectively. Specific gravity ranged between $2 \cdot 71$ and $2 \cdot 74$. Sample A had Cation Exchange Capacity (CEC) value of 10.58 milli-equivalents $/ 100 \mathrm{~g}$ (Meq./100g), sample B had CEC value of 11.76 (Meq./100g) and sample C had CEC value of 12.18 (Meq./100g). Geotechnical tests conducted on samples resulted in hydraulic conductivity $(\mathrm{k})$ of $1.86 \times 10^{-10} \mathrm{~m} / \mathrm{sec}$ for sample A ; $4.12 \times 10^{-8} \mathrm{~m} / \mathrm{sec}$ for sample B and, $2.60 \times 10^{-10} \mathrm{~m} / \mathrm{sec}$ for sample C. The results obtained from the study show that sample $\mathrm{A}$ is the best material for a landfill liner based on the hydraulic conductivity criterion, however all the other samples are also useful and can be improved by addition of little percentage of bentonite. The compaction and compressibility characteristics needed in the specifications for the construction and operation of an engineered landfill using these clayey soils are presented. () JASEM
\end{abstract}

\section{http://dx.doi.org/10.4314/jasem.v19i2.6}

KEYWORDS: Landfill Liner, Waste management, Cation Exchange Capacity, Hydraulic conductivity, Geotechnical characterization

\section{INTRODUCTION}

The liner system in a landfill is the main line of defense against external migration of Leachate and methane gas. A performance standard criterion is a rational approach to developing a liner system. A performance standard describes the expected performance of a lining system and specific design criteria are developed on a site specific basis (Sharma, and Reddy, 2004).

Until about 1982, the predominant liner material used in Landfills was clay. Proper clay liners have a hydraulic conductivity of about $10^{-9} \mathrm{~m} / \mathrm{sec}$ or less. In 1984, the U.S. Environmental Protection Agency's minimum technological requirements for hazardous waste land fill design and construction were introduced by the U.S. Congress in Hazardous and solid waste amendments. In these amendments, Congress stipulated that all new landfills should have double liners and systems for leachate collection and removal (Das, 2009).
In the developed parts of the world, waste management and environmental sustainability have been quite successful. This can be attributed to factors which include; existence of sound environmental law that are strictly enforced and adopted for integrated waste management approach and proper waste collection system. In most developing countries, the high cost of sanitary landfill construction has continued to make the project unrealistic in the past. However, Tufenkji, 2007 reported that; improper waste disposal was the major cause of various water borne diseases that is infecting our society, which resulted to reduction in life expectancy of people; hence, proper waste management should no longer be handled with levity. One of the most effective ways of combating diseases is by maintaining a clean environment, which still boils down to proper disposal of our domestic waste.

Establishment of good sanitary landfill system would help us to achieve an objective of a clean and healthy society in which we live in. Also, the criteria for this 
sanitary landfill design would be heading towards a cost effective design making use of readily available materials in the final chosen site of the project or locally generated materials. This would help in creating more economical sanitary Landfill construction in Nigeria. The contributions of modern sanitary landfills to effective solid waste management in any nation cannot be overemphasized. Landfills is one form of waste management technique options that is universally required of the four basic waste management techniques options, i.e. source reduction, reuse, recycling/ composting and disposal (incineration and landfills). Land filling is both necessary and sufficient. The technology and operation of a modern sanitary landfill ensures protection of public health and the environment. The primary objective of sanitary landfill design is to provide effective control measures to prevent or reduce as far as possible negative effects on the environment, in particular the pollution of surface water, groundwater, soil and air, as well as the resulting risks to human health arising from open dumping of waste. Proper assessment of materials to be used in construction of liner is one of the major aspects of landfill lining system design, and will help in determination of its long-term performance. As it has been said earlier, liner system in a landfill is the main defense line against external migration of leachate and landfill generated gas from having a contaminating effect on environment.

\section{MATERIALS AND METHODS}

Study Area: Clayey soil samples were collected from three different locations namely: Ajetunmobi village Imia, Kajola Local Government, Oyo State; Adegbite area, along Okeho-Iganna road, Okeho, Kajola Local
Government, Oyo State; Arigangan area along Iseyin-Okeho road Iseyin Local Government, Oyo State. The areas were selected based on historical information of pottery activities.

Materials Preparation: Soil samples were collected from depths of clay deposits at the various locations. Sample A was taken from Ajetunmobi village, Imia, at $2.1 \mathrm{~m}$ depth below the ground surface. Sample B was taken from Adegbite area, Okeho, at $2.3 \mathrm{~m}$ depth below the ground surface. Sample $C$ was taken at Arigangan area, Iseyin, at $3.4 m$ depth below the ground surface. These samples were subjected to various experiments necessary to determine its suitability for the intended use.

Methodology: The following experiments were performed for adequate confirmation of good behaviour of clay soils for use as Landfill liner: particle size distribution in accordance with B.S 1377:1990 Part 2:9; Atterberg's limit test in accordance with B.S. 1377:1990, part 2:4,2:5 and 2:6; specific gravity test in accordance with B.S. 1377:1990, part 2:8; moisture content test in accordance with B.S. 1377:1990, part 2:3; compaction test in accordance with B.S. 1377:1990, part 4:4; permeability test: B.S. 1377:1990, part 5:5; consolidation test: B.S. 1377:1990, part 5:3; cation exchange capacity test in accordance with B.S. 1377: 1990, part 3:5.

\section{RESULTS AND DISCUSSION}

Basic Index Property Tests: The basic index property tests result is presented in Table 1. The result was used for characterization of the clay soil.

Table 1 Basic index properties tests result

\begin{tabular}{|c|c|c|c|c|}
\hline Tests type & Results & A & B & $\mathrm{C}$ \\
\hline Natural moisture content & & $2.4 \%$ & $12.9 \%$ & $7.2 \%$ \\
\hline Particle size distribution ( $\%$ fines) & & $32.7 \%$ & $28.3 \%$ & $37.0 \%$ \\
\hline Particle size distribution (maximum particle size) & & $5 \mathrm{~mm}$ & $5 \mathrm{~mm}$ & $5 \mathrm{~mm}$ \\
\hline Specific gravity & & 2.74 & 2.71 & 2.73 \\
\hline Atterberg limit (liquid limit) & & $32.6 \%$ & $33.7 \%$ & $36.9 \%$ \\
\hline Atterberg limit (plastic limit) & & $18.4 \%$ & $15.5 \%$ & $12.5 \%$ \\
\hline Atterberg limit (plasticity index) & & $14.2 \%$ & $18.2 \%$ & $24.4 \%$ \\
\hline
\end{tabular}

The result of natural moisture content on the soil samples show that; Sample A has a natural moisture content of 2.4\%; Sample B has a natural moisture content of 12.9\%; while Sample C has a natural moisture content of $7.2 \%$. Natural moisture content value of clay soil has no effect on its performance as a liner, it only helps in determining the amount of water to be added or removed during compaction process. Normally, compaction of clay soil liner should be done at wet of optimum moisture content (Osinubi and Amadi, 2009).

Particle size distribution results show that; sample A has percentage fines of $32.7 \%$, sample $\mathrm{B}$ has 
percentage fines of $28.3 \%$ and, sample $\mathrm{C}$ has percentage fines of $37.0 \%$; these values fall below the standard value of fines $\geq 50 \%$ specified for clay liner material Frempong and Yanful, 2004 and CGRM, 2007. Hydrometer analyses were conducted sample C contain $10.4 \%$. It is noteworthy that all the samples fall below the standard percentage of clay $\geq 20 \%$ specified by USDA for clay liner material. However, maximum particle size of the three samples was within the value specified by CGRM, 2007. C on the fines to determine the percentage of the clay size particle in the fines. Hydrometer analyses show that sample A contain $6.0 \%$ of clay, sample B contain $3.7 \%$ of clay while

Figure 1 shows the particle size distribution curves resulting from mechanical analysis (which composed of sieve analysis and hydrometer analysis) conducted on soil samples, for sample A, sample B and sample

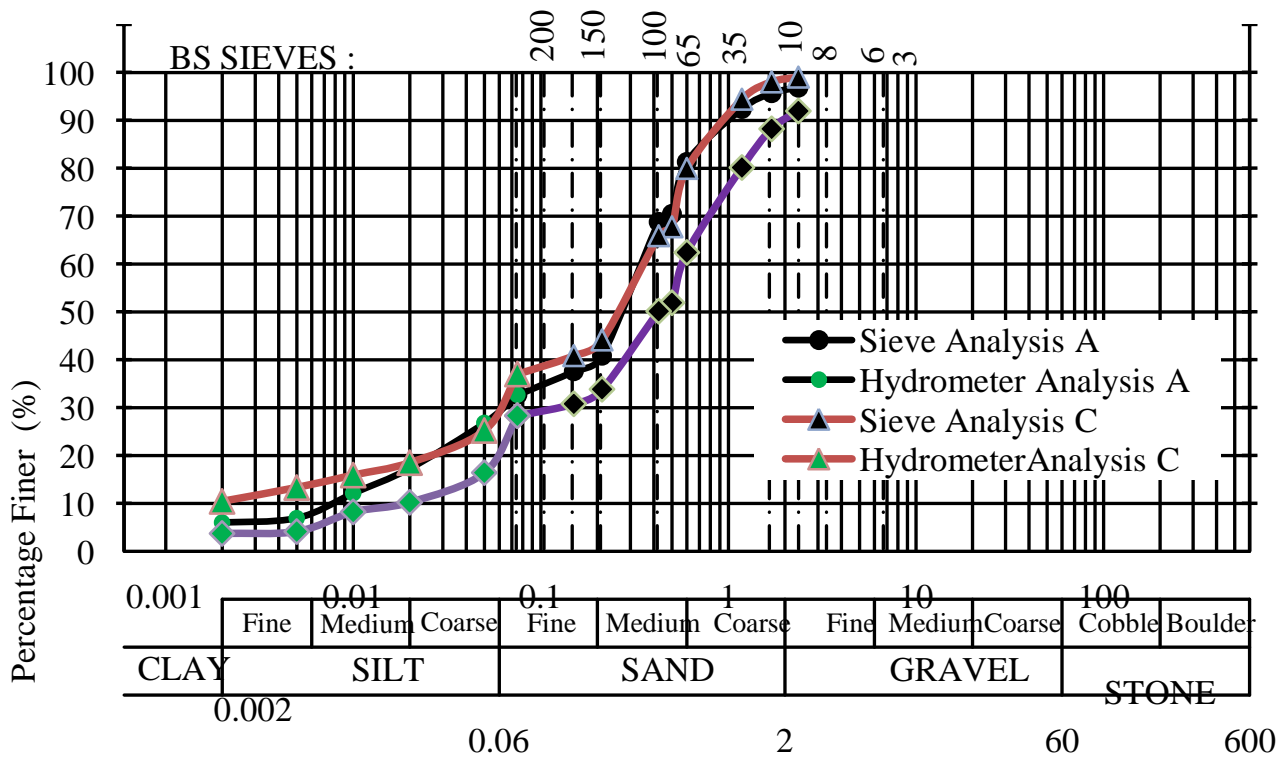

Particle size in $\mathrm{mm}$

Fig. 1 Particle size distribution curve for samples

Atterberg's limit test resulted in sample A, having liquid limit of $32.6 \%$, plastic limit of $18.4 \%$ and plasticity index of $14.2 \%$. Sample B has liquid limit of $33.7 \%$, plastic limit of $15.5 \%$ and plasticity index of $18.2 \%$. Also, Sample C has liquid limit of $36.9 \%$, plastic limit of $12.5 \%$ and plasticity index of $24.4 \%$. All the samples are of adequate liquid limit based on liquid limit value of $\geq 30 \%$ specified by CGRM, 2007, but sample A and sample B are inadequate in plasticity index; as their values fall below plasticity index of $\geq 20 \%$ specified by CGRM, 2007, although specification differ from one place to another.

The specific gravity values for the three samples are: Sample A, 2.74; Sample B, 2.71; Sample C, 2.73.
Specific gravity of $\geq 2.7$ is typical for clayey soils as expected.

Chemical Test : Cations exchange capacity was the only chemical test conducted on the soil samples. The term Cation Exchange Capacity is the measure of the ability of the soil to retain cations, usually expressed as milli-equivalents $/ 100 \mathrm{~g}$ (Meq./100g) of soil. The greater the CEC of soil, the greater the potential of the soil to retain many charged waste constituents, and the more effective the soil is for waste treatment and disposal. CEC value for Sample A was 10.58 Meq./100g; Sample B has CEC value of 11.76 Meq./100g and, that of Sample $\mathrm{C}$ was 12.18 Meq./100g, these values fall within the range of values expected for clayey soils with kaolinitic 
mineralogy Williams, 1999, Yong and Mulligan, 2003. The relationship between the percentage of fines in the soil samples and CEC values is shown in Fig. 2.

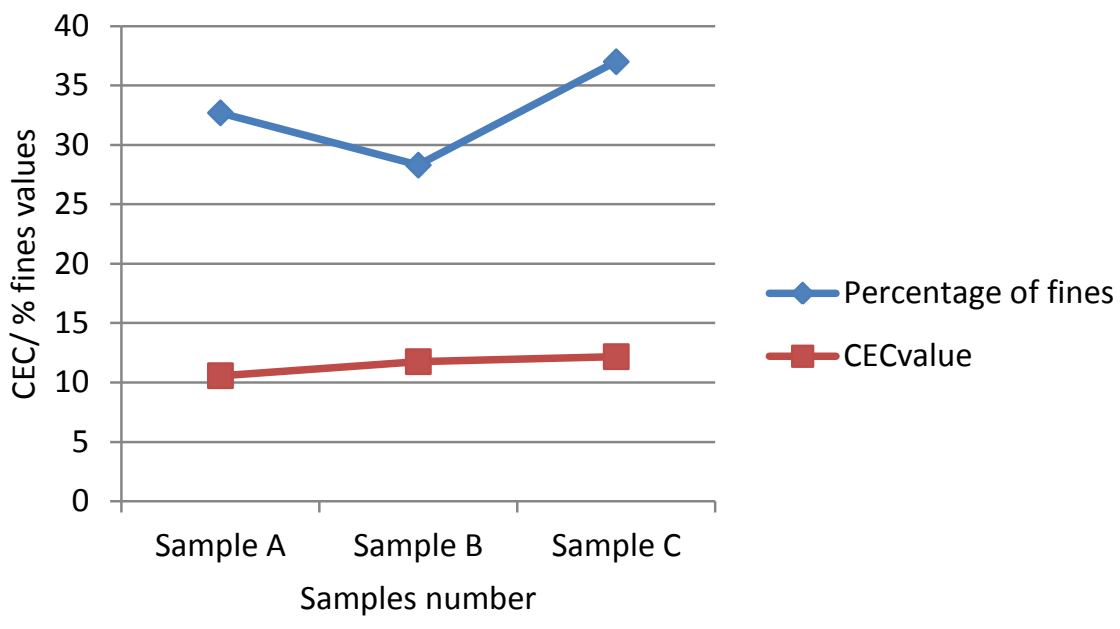

Fig. 2 Variation of CEC values with percentage fines

From Fig. 2 it can be observed that the variation of CEC values with percentage fines is not linear. Sample A with greater percentage fines than Sample $\mathrm{B}$, has a smaller CEC value. The reason was that, only clay mineral in a given soil sample is responsible for retention of Cations; percentage clay in Sample B may be greater than that in Sample A.

Geotechnical Tests: Compaction test is one of most important geotechnical test that must be conducted on soil sample, in order to determine whether it is suitable or not suitable to be used as clay liner in sanitary landfill. The results of laboratory test equip an Engineer with adequate tool to make a right judgment about the maximum density that must be achieved on site during compaction. The results of compaction for the three samples are presented in Fig. 3

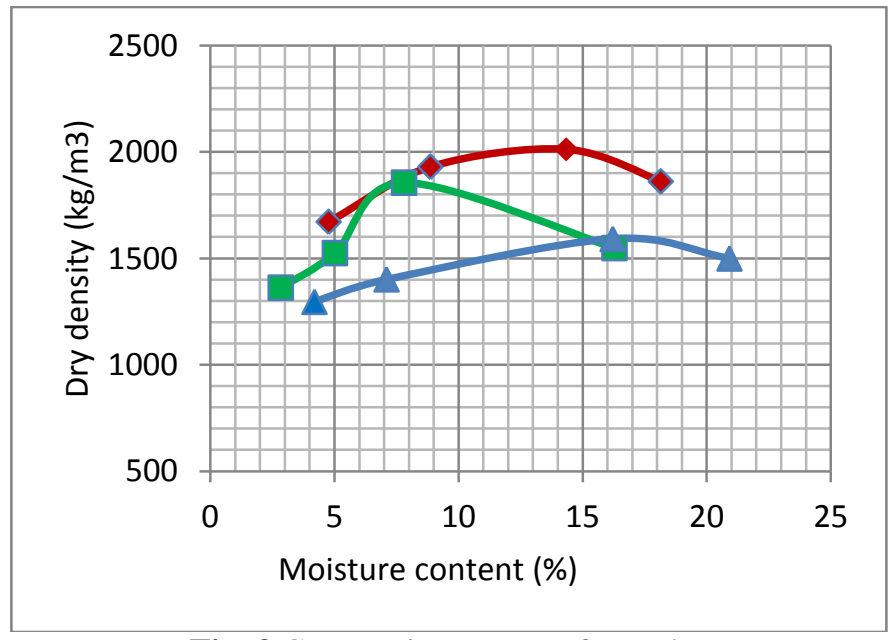

Fig. 3 Compaction curves of samples

Compaction results show that; Sample A has maximum dry density of $2010 \mathrm{~kg} / \mathrm{m}^{3}$ and optimum moisture content of 14.3\%; Sample B has maximum dry density of $1860 \mathrm{~kg} / \mathrm{m}^{3}$ and optimum moisture content of 7.8\%; Sample $\mathrm{C}$ has maximum dry density of $1590 \mathrm{~kg} / \mathrm{m}^{3}$ and optimum moisture content of $16.2 \%$. The soil moisture/density relationship is critical to proper liner construction, as it has been said 
earlier; compaction on site must always be done at wet of optimum moisture content (Osinubi and Amadi, 2009).

Consolidation coefficients for various soil samples were determined; Table 2 shows the coefficient of consolidation $\left(c_{v}\right)$ and the coefficient of volume compressibility $\left(\mathrm{m}_{\mathrm{v}}\right)$ for the samples. These compaction and compressibility characteristics are needed in the specifications for the construction and operation of an engineered landfill using these clayey soils.

Table 2 Coefficients of consolidation

\begin{tabular}{lll}
\hline SAMPLE & $\mathrm{c}_{\mathrm{v}}\left(\mathrm{cm}^{2} / \mathrm{s}\right)$ & $\mathrm{m}_{\mathrm{v}}\left(\mathrm{kN}^{-1}\right)$ \\
\hline $\mathrm{A}$ & $1.81 \times 10^{-3}$ & $0.31 \times 10^{-3}$ \\
$\mathrm{~B}$ & $1.67 \times 10^{-3}$ & $0.33 \times 10^{-3}$ \\
$\mathrm{C}$ & $1.08 \times 10^{-3}$ & $0.31 \times 10^{-3}$ \\
\hline
\end{tabular}

Consolidation curves for clay samples are presented in Fig. 4, Fig. 5 and Fig. 6.

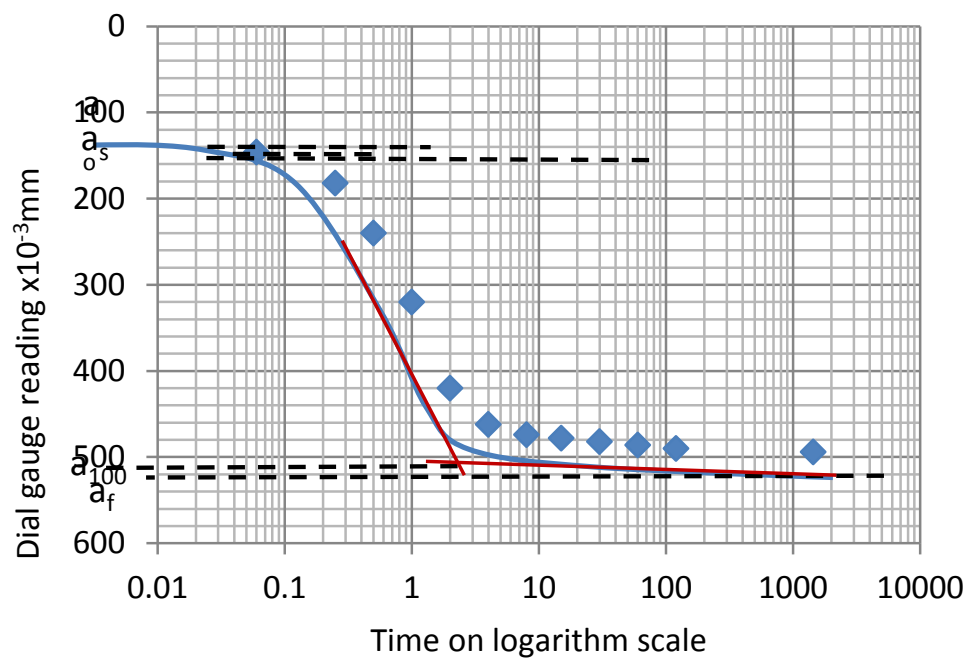

Fig. 4 Consolidation curve for Sample A

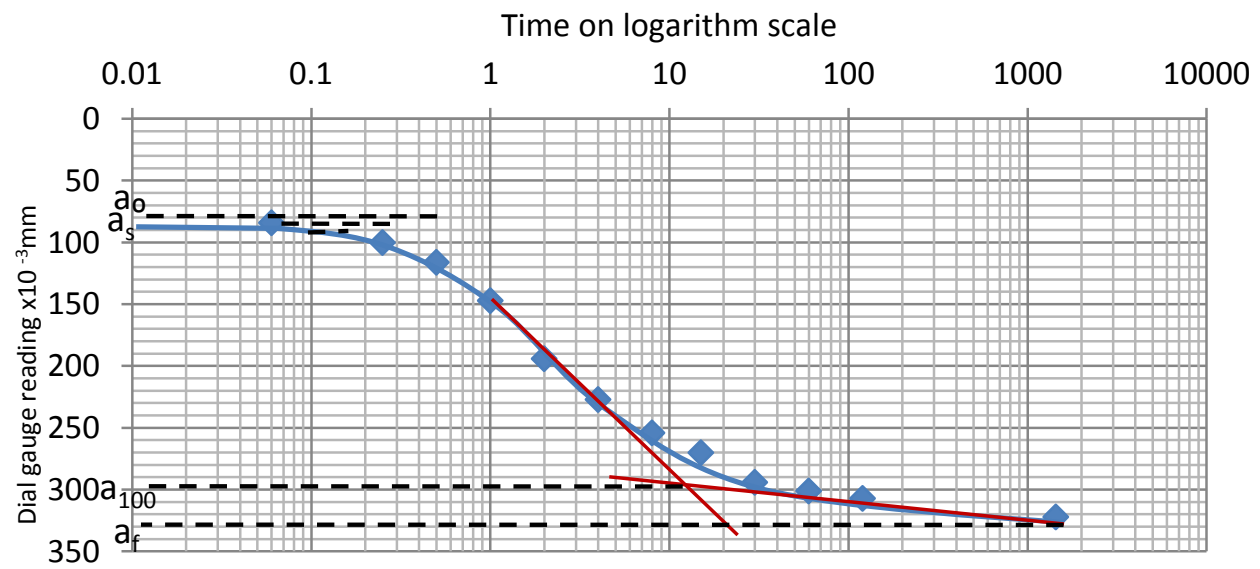

Fig. 5 Consolidation curve for Sample B 


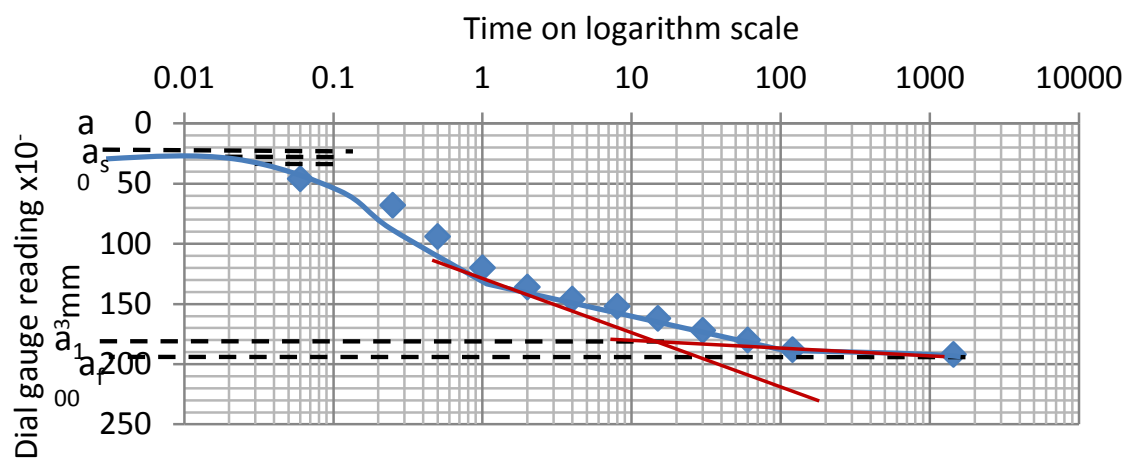

Fig. 6 Consolidation curve for Sample C

Compression ratio for samples can be calculated by using the following formula (Garg, 2009)

$r_{o}=\frac{a_{o}-a_{S}}{a_{o-} a_{f}} \quad$ (1) Where $r_{o}$ is the initial compression ratio; $a_{o}$ is the start of compression process; $a_{s}$ is the start of consolidation process and $a_{f}$ is the limit of secondary consolidation process. The primary compression ratio can be expressed according to Eq. (2) shows below.

$r_{p}=\frac{a s-a_{100}}{a_{0}-a_{f}}$ (2) Also, $r_{p}$ is the primary compression ratio; $a_{o}, a_{s}$ and $a_{f}$ are as defined in Eq. (1) while $a_{100}$ is the limit of primary consolidation process. Equation (3) represents the expression for secondary compression $\left(r_{s}\right)$, while $r_{o}$ and $r_{p}$ are as in Eq. (1) and Eq. (2) $r_{s}=1-\left(r_{o}+r_{o}\right)$ (3)

Table 3 gives the summary of compression ratio values for all samples

Table 3. Compression ratio summary

\begin{tabular}{llll}
\hline $\begin{array}{l}\text { Sample } \\
\text { name }\end{array}$ & $\begin{array}{l}\boldsymbol{r}_{\boldsymbol{o}} \\
\text { values }\end{array}$ & $\begin{array}{l}\boldsymbol{r}_{\boldsymbol{o}} \\
\text { values }\end{array}$ & $\%$ \\
\hline A & 0.13 & 0.84 & 0.03 \\
B & 0.10 & 0.80 & 0.10 \\
C & 0.12 & 0.81 & 0.07 \\
\hline
\end{tabular}

Results of hydraulic conductivity test conducted on the soil samples gave hydraulic conductivity " $k$ " of $1.86 \times 10^{-10} \mathrm{~m} / \mathrm{sec}$ for Sample A; Sample B has hydraulic conductivity " $k$ " equal to $4.12 \times 10^{-8} \mathrm{~m} /$ sec and Sample $C$ has hydraulic conductivity " $k$ " of $2.60 \times 10^{-10} \mathrm{~m} / \mathrm{sec}$. Hydraulic conductivity is the final test to approve the compliance of particular clay materials for construction of sanitary landfill clay liner. When the material to be used for the construction of a clay liner does not meet all of the criteria stated in material characterization, additional testing are required to demonstrate that the "asconstructed" clay liner will have a field hydraulic conductivity of $1 \times 10^{-9} \mathrm{~m} / \mathrm{sec}$ or less as reported by USEPA, 1994, CGRM, 2007 and Amadi and Eberemu, 2012.

Conclusion: The present study observed the geotechnical characterization of clayey materials to be used as landfill liner. The results of various tests show that, all the soil samples do not contain the required content of fines (i.e. silt and clay) as reported in literature Haxo et al, 1982, CGRM, 2007 and Osinubi and Amadi, 2009. Materials with high silt content should not be considered acceptable. Such materials would not compact well and are highly erodible. The samples liquid limit fall, within the acceptable range but, only Sample C plasticity index fall within the specified range. Hydraulic conductivity of a sanitary landfill liner is the most important parameter to consider in materials selection. Even, when the materials to be used as landfill liner do not meet all other requirements it can be selected on the basis of meeting the hydraulic conductivity criterion alone. Apart from materials selection, another important factor that contributes to adequate performance of landfill liner is proper liner construction. Soil moisture / density relationship is critical to proper construction. Adequate quality control on the site will go a long way in improving the performance of the clay liner. The results obtained from the study show that, samples sample A 
and sample $\mathrm{C}$ have hydraulic conductivity values suitable for use as landfill liners. Their values are lower than the specification of hydraulic conductivity, $\mathrm{k} \leq 1 \times 10^{-9} \mathrm{~m} / \mathrm{sec}$ (USEPA, 1994, CGRM, 2007 and Amadi and Eberemu, 2012). The

\section{REFERENCES}

B.S.1377, "Methods of Testing for Soil for Civil Engineering Purpose", British Standard Institute, 389 Chiswick High Road London, W4 4AL, 1990.

Canadian Government Report, Manitoba (CGRM),Technical Reference Document for Liquid Manure Storage Structures, “Compacted Clay Liners", February, 2007.

Das, B. M., "Principles of Geotechnical Engineering SI Version Category: Cengage Learning Publisher, Stamford, CT 06902 USA, 2009, p. 544.

Frempong, E. M. and Yanful, E. K. "Compatibility of three tropical clayey soils with MSW landfill leachate." Submitted to 57th Canadian Geotechnical Conference, Quebec City, Canada, Oct. 24-27, 2004.

Garg, S.K.., "Soil Mechanics and Foundation Engineering”, Khanna Publishers, 4575/15, Onkar House, Opp. School Daryaganj, New Delhi, 2009, pp. 224-263.

Haxo, H.E., White, R.M., Haxo, P.D. and Fong, M.A., "Liner Materials Exposed to Municipal Solid Waste Leachate" EPA-600/2-82/097 (NTIS No.PB 83147-801), 1982, US Environmental Protection Agency, Cicinnati, Ohio.

Osinubi, K.J. and Amadi, A. A. Hydraulic performance of compacted lateritic soil-bentonite mixtures permeated with municipal solid waste landfill leachate. In: Transportation Research Board (TRB) 88th Annual meeting CD-ROM, 11-15th Jan., 2009, Washington DC, USA. Paper \# 09-0620, pp 1-18 samples can, thus be improved by addition of little percentage of bentonite.

Acknowledgement: The author would like to acknowledge the contribution E.O Eyinade in data collection.

Sharma, H. D., and Reddy, K. R. (2004). Geoenvironmental engineering: Site remediation, waste containment, and emerging waste management technologies, Wiley, Hoboken, NJ.

Tufenkji, N., 2007. Modeling microbial transport in porous media:traditional approaches and recent developments. Adv. Water Resour. 30, 14551469.

US Environmental Protection Agency (1994) Review of Liner and Cap Regulations for Landfills.

EPA/600/A-94/246., Risk Reduction Engineering Laboratory, Office of Research and Development, U.S. EPA, Cincinnati, Ohio, 45268

Williams, G.M., "Natural Attenuation of Contaminants in a Lacustrine Sand Aquifer at Villa Farm, UK", Proc. Sardinia 99, Seventh International Landfill Symposium, (eds. T.H. Christensen, R. Cossu and R. Stegmann), CISA Publisher, Cagliari, vol. 4, 1999, pp. 229-236.

Workman, J., and Keeble, R., "Design and Construction of Liner Systems," Christensen et al. (eds), Sanitary Landfilling: Process, Technology and Environmental Impact, Academic Press, New York, 1989, pp. 301-309

Yong, R.N. and Mulligan, C.N., Natural Attenuation of Contaminants in Soils. Lewis Publishers, Boca Raton, Fl., 2003 